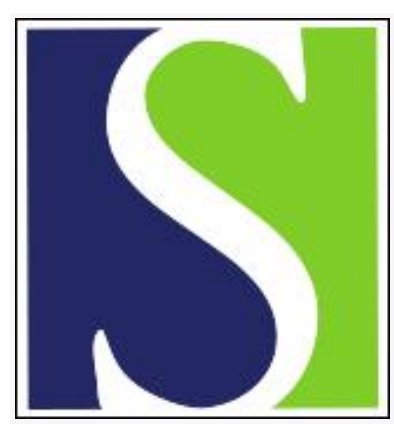

Scand J Work Environ Health 1984;10(6):511-515

https://doi.org/10.5271/sjweh.2292

Issue date: Dec 1984

\title{
Alcoholism and occupation.
}

by Olkinuora $\mathrm{M}$

This article in PubMed: www.ncbi.nlm.nih.gov/pubmed/6535254 


\title{
Alcoholism and occupation
}

\author{
by Martti Olkinuora, MD ${ }^{1}$
}

\begin{abstract}
OLKINUORA M. Alcoholism and occupation. Scand $J$ Work Environ Health 10 (1984) 511-515. Occupational roles are a dominant force in many aspects of social life. Occupation signifies a complex of social and psychological factors that reflect intelligence, education, personality, ambition, social status, and life-style. The consumption of alcohol and alcoholism have many correlations with occupational roles. Mortality from cirrhosis of the liver reflects the per capita consumption of alcohol. In certain occupations such mortality rates are clearly above average. The highest risk is found in occupations associated with the serving of food and beverages. A Finnish study has shown that the alcohol-related use of health services among males is the highest among unskilled workers, painters, seamen, and construction workers and the lowest among executives and farmers. Many population studies have shown that bluecollar workers and laborers have the highest level of drinking. This pattern is not necessarily true among females. The risk factors associated with occupation include the availability of alcohol at work, social pressure to drink on the job, separation from normal social relationships, and freedom from supervision. The opportunity to obtain alcoholic beverages relatively inexpensively, when combined with social pressure by peers to drink heavily, is an especially powerful explanation for high rates of alcoholism within an occupation.
\end{abstract}

Key terms: heavy drinking, problem drinking, social class.

Alcoholism is widely seen as a multietiologic phenomenon to which genetic, biological, social, and psychological factors contribute. Occupation means a complex of social and psychological factors that reflect intelligence, education, personality, ambition, social status, and life-style.

The relationship between occupation and alcoholism received considerable attention during the 1970s, mainly because of the ascendancy of the idea that the potentially most favorable intervention with a problem drinker could take place through identification at the workplace. Occupational roles are a dominant force in many aspects of social life in both Western and other societies. As this force is associated with a number of social concerns that range from population dynamics and divorce rates to suicide rates and other forms of self-destructive behavior, understanding the role of occupation in the etiology of social problems is both important and useful (14).

\section{Mortality statistics}

Despite certain inaccuracies, it is widely accepted that variation in the prevalence of death from cirrhosis of the liver reflects the true variation in the prevalence of alcohol consumption.

\footnotetext{
1 Department of Occupational Medicine, Institute of Occupational Health, Helsinki, Finland.
}

Reprint requests to: Dr M Olkinuora, Institute of Occupational Health, Haartmaninkatu 1, SF-00290 Helsinki, Finland.
Countries with a high per capita consumption of alcohol have a high mortality from liver cirrhosis (eg, France, Italy, Portugal, and Spain). The opposite is true for countries with a low per capita consumption of alcohol (eg, Sweden, The Netherlands, Finland, and Norway) (2).

The 20 occupations with the highest rates of liver cirrhosis in England and Wales are shown in table 1. The table shows that the mortality rates of the occupations in the table range from 2.7 to 15.8 times the average. Occupations concerned with the service of food and beverage account for 6 of the top 20 occupations. Another six occupations with a high stan-

Table 1. Standardized mortality ratio (SMR) for liver cirrhosis according to occupation - England and Wales, 1970-1972 (7).

\begin{tabular}{lr}
\hline Occupation & SMR \\
\hline & 100 \\
Average occupation & 1576 \\
Publicans, innkeepers & 781 \\
Deck, engineering officers and pilots, ship & 633 \\
Barmen, barmaids & 628 \\
Deck and engine room ratings, barge and boatmen & 595 \\
Fishermen & 506 \\
Proprietors and managers, boardinghouses and hotels & 392 \\
Finance, insurance brokers, financial agents & 385 \\
Restaurateurs & 377 \\
Truck drivers' mates, van guards & 354 \\
Cooks & 323 \\
Shunters, pointsmen & 319 \\
Winders, reelers & 319 \\
Electrical engineers (so described) & 314 \\
Authors, journalists and workers in related occupations & 314 \\
Medical practitioners (qualified) & 294 \\
Garage proprietors & 290 \\
Signalmen and crossing keepers, railroads & 281 \\
Maids, valets, and workers in related services & 269 \\
Tobacco preparers and product makers & 266 \\
Metallurgists &
\end{tabular}


dardized mortality ratio concerned transport. Whitecollar occupations are also represented.

Mortality statistics from the United States for 1959 revealed that the occupations with standardized mortality ratios (SMR) above average for liver cirrhosis were waiters, bartenders, and counter workers $(\mathrm{SMR}=392)$, longshoremen and stevedores $(\mathrm{SMR}=$ 342), transport laborers (SMR $=314)$, cooks (SMR = $278)$, and musicians $($ SMR $=278)(3)$.

Table 2. Days of alcohol-related hospital care and visits to outpatient clinics per year among men in proportion to every 1000 representatives (over the age of 15 years) of their respective occupational group (11).

\begin{tabular}{|c|c|c|}
\hline Occupational group & $\begin{array}{c}\text { Days of } \\
\text { hospital } \\
\text { care }\end{array}$ & $\begin{array}{c}\text { Visits to } \\
\text { outpatient } \\
\text { clinics }\end{array}$ \\
\hline Unskilled workers & 5376 & 904 \\
\hline Painters & 2400 & 533 \\
\hline Seamen & 2175 & 323 \\
\hline Construction workers & 2033 & 490 \\
\hline Forestry and floating workers & 1946 & 125 \\
\hline Operators & 1919 & 655 \\
\hline Artists, authors, journalists & 1634 & 268 \\
\hline Dockers and warehouse workers & 1404 & 313 \\
\hline Shopkeepers & 1348 & 275 \\
\hline Textile workers & 1281 & 154 \\
\hline Molders & 1172 & 188 \\
\hline Salesmen & 889 & 137 \\
\hline Woodworkers & 847 & 176 \\
\hline Architects, engineers, technicians & 836 & 111 \\
\hline Iron and metal ware workers & 806 & 225 \\
\hline Policemen and guards & 643 & 133 \\
\hline Transport service personnel & 615 & 64 \\
\hline Agricultural workers & 532 & 32 \\
\hline Electrical workers & 528 & 178 \\
\hline Shop personnel & 452 & 84 \\
\hline \multicolumn{3}{|l|}{ Chauffeurs and railroad } \\
\hline $\begin{array}{l}\text { engineers } \\
\text { Administrative and technical }\end{array}$ & 448 & 132 \\
\hline executives & 320 & 129 \\
\hline Farmers and farm managers & 311 & 39 \\
\hline
\end{tabular}

Table 3. Sum of days of alcohol-related hospital care and visits to outpatient clinics per year among women in proportion to 1000 representatives (over the age of 15 years) of their respective occupational group (11).

\begin{tabular}{lc}
\hline Occupational group & $\begin{array}{c}\text { Days of hospital care } \\
+ \text { visits to outpatient } \\
\text { clinics }\end{array}$ \\
\hline Unskilled workers & 431 \\
Architects, engineers, technicians & 284 \\
Iron and metal ware workers & 148 \\
Construction workers & 116 \\
Artists, authors, journalists & 108 \\
Electrical workers & 69 \\
Dockers and warehouse porters & 46 \\
Housekeepers & 27 \\
Shopkeepers & 25 \\
Waiters & 23 \\
Operators & 16 \\
Workers in the fields of hygiene & 14 \\
and cleaning & 12 \\
Shop assistants & 12 \\
Clerks & 11 \\
Textile workers & 10 \\
Transport service personnel & 7 \\
Health care personnel & 7 \\
Teachers & 6 \\
Farmers' wives & \\
\hline
\end{tabular}

An exhaustive literature review of mortality statistics has been presented by Whitehead \& Simpkins (14).

\section{Use of health services}

Several studies have shown that individuals from certain occupations (executives, seamen, service personnel, and commercial travelers) are overrepresented among those referred to alcoholism treatment agencies (8). In Finland an extensive study (11) on the alcohol-related use of health services revealed that, for men, the number of days of hospital care due to alcohol and the number of visits to outpatient clinics for the same reason were the highest among unskilled workers, followed by painters, seamen, and construction workers, and the lowest among administrative and technical executives and farmers (table 2). Unskilled workers were also the highest ranking group for women; the lowest ranking groups were health workers, teachers, and farmers' wives (table 3). The total use of health services for this reason was considerably lower among women. (Because of the low number of cases the days of hospital care and the number of visits to outpatient clinics have been combined for the women.)

\section{Population studies}

In a national survey of drinking practices throughout the United States in 1964-1965 with a random sample representative of the adult household population, the highest proportion of abstainers was farm owners. Professional families had a slightly higher proportion of drinkers than did business people, the latter having relatively higher proportions of both heavy drinkers and heavy-escape drinkers. Operative (semiskilled workers), semiprofessional, technical, and service workers (including domestics) were somewhat above average in their proportions of heavy and heavy-escape drinkers (1) (table 4).

Job characteristics and drinking practices were studied in the Boston metropolitan area (4). Among the men, blue-collar workers and laborers had the highest levels of drinking (table 5). The differences between laborers and blue-collar workers and the rest of the sample remained even when men under the age 25 years were considered separately. No evidence was found to support the contentions that social isolation predisposed workers to heavy drinking or that people with flexible work schedules drank more.

The Finnish Foundation for Alcohol Studies has carried out a study to determine changes in Finnish drinking habits since 1969, when more liberal legislation was enacted on alcohol distribution. Nearly 3000 persons from 15 to 69 years of age, who represented the entire Finnish population, were inter- 
Table 4. Drinkers, heavy drinkers, and heavy-escape drinkers by occupation (1).

\begin{tabular}{|c|c|c|c|c|c|}
\hline \multirow{2}{*}{ Chief breadwinner's occupation } & \multirow{2}{*}{$\begin{array}{l}\text { Total } \\
\text { sample } \\
\text { (N) }\end{array}$} & \multicolumn{2}{|c|}{ Drinkers } & \multirow{2}{*}{$\begin{array}{c}\text { Heavy } \\
\text { drinkers } \\
(\%)\end{array}$} & \multirow{2}{*}{$\begin{array}{c}\text { Heavy-escap } \\
\text { drinkersa, b } \\
(\%)\end{array}$} \\
\hline & & $\mathbf{N}$ & Percent & & \\
\hline $\begin{array}{l}\text { Professional } \\
\text { Manager, proprietor, official } \\
\text { Semiprofessional, technician } \\
\text { Farm owner } \\
\text { Clerk } \\
\text { Sales person } \\
\text { Craftsman, foreman } \\
\text { Operator } \\
\text { Service worker } \\
\text { Laborer (including farm labor) }\end{array}$ & $\begin{array}{r}288 \\
512 \\
81 \\
134 \\
217 \\
141 \\
558 \\
471 \\
179 \\
149\end{array}$ & $\begin{array}{r}234 \\
382 \\
60 \\
54 \\
155 \\
113 \\
366 \\
287 \\
106 \\
83\end{array}$ & $\begin{array}{l}81 \\
75 \\
78 \\
42 \\
70 \\
79 \\
66 \\
62 \\
61 \\
57\end{array}$ & $\begin{array}{l}11 \\
20 \\
21 \\
14 \\
16 \\
14 \\
17 \\
24 \\
23 \\
18\end{array}$ & $\begin{array}{r}6 \\
10 \\
11 \\
5 \\
9 \\
7 \\
8 \\
14 \\
10 \\
11\end{array}$ \\
\hline
\end{tabular}

a Base: total number of drinkers.

- The respondent was classified as an escape drinker if he chose two or more of five items reflecting "escape reasons" (eg, "I drink when I want to forget everything").

Table 5. Percentage of abstainers and mean number of drinks per day by sex and occupational group (4).

\begin{tabular}{|c|c|c|c|c|c|c|}
\hline \multirow{2}{*}{$\begin{array}{l}\text { Occupational } \\
\text { group }\end{array}$} & \multicolumn{2}{|c|}{ Number } & \multicolumn{2}{|c|}{$\begin{array}{c}\text { Abstainers } \\
(\%)\end{array}$} & \multicolumn{2}{|c|}{$\begin{array}{l}\text { Mean number of } \\
\text { drinks per day }\end{array}$} \\
\hline & Men & Women & Men & Women & Men & Women \\
\hline $\begin{array}{l}\text { Professionals, technical workers } \\
\text { Self-employed, managerial personnel } \\
\text { Clerical and sales personnel } \\
\text { Skilled workers } \\
\text { Semiskilled workers } \\
\text { Service personnel } \\
\text { Unskilled workers } \\
\end{array}$ & $\begin{array}{r}519 \\
229 \\
247 \\
272 \\
182 \\
182 \\
71 \\
\end{array}$ & $\begin{array}{r}447 \\
110 \\
660 \\
24 \\
87 \\
247 \\
6 \\
\end{array}$ & $\begin{array}{l}47 \\
36 \\
44 \\
31 \\
34 \\
35 \\
21\end{array}$ & $\begin{array}{l}51 \\
42 \\
53 \\
50 \\
31 \\
39 \\
50\end{array}$ & $\begin{array}{l}1.1 \\
1.3 \\
1.0 \\
1.4 \\
1.3 \\
1.3 \\
1.8 \\
\end{array}$ & $\begin{array}{l}0.7 \\
0.8 \\
0.6 \\
0.6 \\
0.6 \\
0.6 \\
0.4\end{array}$ \\
\hline Total & 1772 & 1581 & 16 & 26 & 1.2 & 0.7 \\
\hline
\end{tabular}

viewed in the autumn of 1976 (12). Some of the results are presented in table 6.

It was revealed that the consumption of alcohol and the proportion of consumption for intoxication varied greatly in different occupational groups among both men and women (tables $7 \& 8$ ). Whereas male professionals consumed $506 \mathrm{cl}$ of absolute alcohol yearly and the proportion of consumption for intoxication was $44 \%$, the corresponding figures for blue-collar workers were $760 \mathrm{cl}$ and $74 \%$. Among women consumption was the highest among professionals, but blue-collar workers still had a higher proportion of consumption for intoxication.

Studies of social class factors in alcoholism often yield contradictory results. Some well-planned and well-executed studies have shown a higher incidence of heavy drinking at the higher socioeconomic levels; there are equally solid studies which have produced opposite results (6).

In any case, the annual incidence of alcoholism among men in a Swedish community cohort $(\mathrm{N}=$ 2550 ), prospectively observed between 1957 and 1972, was found to be the highest for blue-collar workers (340 per 100000$)$. The rate was much higher than for self-employed businessmen, artisans, and farmers (230 per 100000$)$ or for white-collar employees (190 per 100000$)$. The findings support earlier suggestions that class creates alcoholics at different rates (5).
Table 6. Changes in Finnish drinking habits from 1969 to 1976 (12).

\begin{tabular}{lrr}
\hline & 1969 & 1976 \\
\cline { 2 - 3 } & & \\
Abstainers (percentage of total) & 35 & 20 \\
$\quad \begin{array}{l}\text { Women } \\
\text { Men }\end{array}$ & 9 & 9 \\
$\begin{array}{l}\text { Consumption for intoxication } \\
\text { (percentage of total consumption) }\end{array}$ & & \\
$\quad \begin{array}{l}\text { Women } \\
\text { Men }\end{array}$ & 26 & 39 \\
$\begin{array}{l}\text { Amount consumed by women } \\
\text { (percentage of total) }\end{array}$ & 58 & 65 \\
$\begin{array}{l}\text { Female users' annual consumption } \\
\text { (percentage of male users' consumption) }\end{array}$ & 17 & 21 \\
\hline
\end{tabular}

\section{Risk factors in occupations}

After a review of the extensive literature on the subject, the following eight factors emerged as the most commonly suggested explanations of why certain occupations have high rates of alcohol-related problems (8): (i) availability of alcohol at work (eg, the drink trade), (ii) social pressure to drink at work (eg, servicemen, seamen), (iii) separation from normal social or sexual relationships (eg, servicemen, seamen, commercial travelers), (iv) freedom from supervision (eg, executives, doctors, lawyers), (v) very high or very low income levels (eg, professionals, the unemployed, unskilled workers), (vi) col- 
Table 7. Annual consumption of alcohol (centiliters of absolute alcohol) among urban men over 20 years of age according to their occupation in $1976(12)$

\begin{tabular}{|c|c|c|c|c|c|}
\hline $\begin{array}{l}\text { Occupational } \\
\text { status }\end{array}$ & $\mathbf{N}$ & $\begin{array}{l}\text { Consumption } \\
\text { for intoxication } \\
\text { (cl) }\end{array}$ & $\begin{array}{l}\text { Other } \\
\text { consumption } \\
\text { (cl) }\end{array}$ & $\begin{array}{c}\text { Total } \\
\text { consumption } \\
\text { (ci) }\end{array}$ & $\begin{array}{l}\text { Proportion of } \\
\text { consumption for } \\
\text { intoxication }(\%)\end{array}$ \\
\hline $\begin{array}{l}\text { Self-employed } \\
\text { Professionals } \\
\text { Workers } \\
\text { Others }\end{array}$ & $\begin{array}{r}62 \\
231 \\
299 \\
74\end{array}$ & $\begin{array}{l}434 \\
223 \\
562 \\
489\end{array}$ & $\begin{array}{l}145 \\
283 \\
198 \\
219\end{array}$ & $\begin{array}{l}579 \\
506 \\
760 \\
708\end{array}$ & $\begin{array}{l}75 \\
44 \\
74 \\
69\end{array}$ \\
\hline Total & 666 & 424 & 226 & 650 & 65 \\
\hline
\end{tabular}

Table 8. Annual consumption of alcohol (centiliters of absolute alcohol) among urban women over 20 years of age according to their occupation in $1976(12)$.

\begin{tabular}{|c|c|c|c|c|c|}
\hline $\begin{array}{l}\text { Occupational } \\
\text { status }\end{array}$ & $N$ & $\begin{array}{l}\text { Consumption } \\
\text { for intoxication } \\
\text { (cl) }\end{array}$ & $\begin{array}{l}\text { Other } \\
\text { consumption } \\
\text { (cl) }\end{array}$ & $\begin{array}{c}\text { Total } \\
\text { consumption } \\
\text { (cl) }\end{array}$ & $\begin{array}{l}\text { Proportion of } \\
\text { consumption for } \\
\text { intoxication }(\%)\end{array}$ \\
\hline $\begin{array}{l}\text { Self-employed } \\
\text { Professionals } \\
\text { Workers } \\
\text { Others }\end{array}$ & $\begin{array}{r}28 \\
351 \\
212 \\
90\end{array}$ & $\begin{array}{l}23 \\
75 \\
85 \\
29\end{array}$ & $\begin{array}{r}98 \\
139 \\
87 \\
86\end{array}$ & $\begin{array}{l}121 \\
214 \\
172 \\
115\end{array}$ & $\begin{array}{l}19 \\
35 \\
49 \\
25\end{array}$ \\
\hline Total & 681 & 70 & 114 & 184 & 38 \\
\hline
\end{tabular}

lusion by colleagues (fear of dismissal or exploitment of a colleague's incapacity), (vii) strain and stress [eg, danger (seamen, servicemen), responsibility (doctors, lawyers, executives), job insecurity (actors), boredom, etc], and (viii) recruitment of "unusual people" predisposed to heavy drinking (eg, the Merchant Navy).

In an attempt to ascertain whether a high-risk occupation attracts individuals who are already heavy drinkers or "alcoholics" or who appear likely to become such and to examine the effects of "high-" and "low-risk" work situations over time on drinking habits, the alcohol-related problems of 150 new recruits to a "high-risk" industry (alcohol production) were compared with a reference group of 150 men newly recruited to "low-risk" jobs. Initial data (at the start of employment) indicated that the former were significantly heavier drinkers with poorer employment records. Follow-up interviews one year and two to three years later indicated that the current type of job was closely associated with alcohol consumption and alcohol-related problems.

Roman \& Trice (10) have pointed out that most adult males who are deviant drinkers occupy work roles throughout most of the period during which their drinking turns into alcohol addiction. There are two general categories of risk factors relevant to their work organizations, absence of supervision and low visibility of job performance. The nine occupational risk factors are: (i) nebulous production goals, (ii) flexible work hours, (iii) low visibility of work performance, (iv) work addiction, (v) occupational obsolence, (vi) novel work status, (vii) drinking as part of the regular work role, (viii) mutual benefits, and (ix) reduced social control.
According to Von Wiegand's studies (13) about alcoholism in industry in the United States only three variables have been found that affect the prevalence of alcoholism in any given company. They are: (i) the male-female sex ratio of the employee population (the prevalence increasing of course as the ratio of the male population rises); (ii) the average age of the employee population (the incidence rising with the average age); and (iii) the company's degree of permissiveness in tolerating incidents of unsatisfactory attendance, behavior, or job performance before discharging problem employees (the incidence rising with the degree of permissiveness).

A thorough analysis of 39 structural characteristics of occupations specified in the literature as associated with elevated rates of alcoholism revealed that the opportunity to obtain alcoholic beverages relatively inexpensively is one of the most important factors affecting the rate of alcoholism and the consumption of alcohol (14). However, this factor, in combination with social pressure by peers to drink heavily - especially in a work milieu tolerant of heavy drinking and characterized by a preponderance of young workers, is an especially powerful explanation of high rates of alcoholism and consumption within an occupation.

\section{Discussion}

Alcoholism - no matter how it is defined - is an enormous problem in worklife. The National Council of Alcoholism in the United States conducted a study that revealed alcoholism in at least $5.3 \%$ of the total labor force, ie, approximately 4 million em- 
ployed alcoholics in the United States (13). From the studies reviewed, it seems that certain occupations entail a greater risk of alcoholism than others. Whether these "risk occupations" attract people predisposed to become alcoholics or whether these occupations "cause" alcoholism is an open question. Plant's study (8) lends support to both directions. Major changes in drinking habits occurred with changes in job status; and levels of consumption, perceptions of the use of alcohol at work, and alcohol-related problems were largely determined by current occupational circumstances.

Heavy drinking and alcoholism as a problem of worklife call for preventive efforts and treatment. As Von Wiegand (13) says, industry provides the single most effective tool to motivate the alcoholic to accept treatment. However, greater proscription against heavy drinking and drinking on the job, as well as a decreased accessibility to alcoholic beverages, go a long way toward reducing the prevalence of heavy drinking and alcoholism in occupational categories associated with high rates of drinking and health damage (14). One attempt to solve this problem has been the building up of systems for the referral of problem drinkers to treatment, based on agreements at each workplace. This kind of system, based on the recommendations of central worker and employer organizations, was established in Finland in 1972 (9).

\section{References}

1. Cahalan D, Cisin IH. American drinking practices: Summary of findings from a national probability sample: I Extent of drinking by population subgroups. Q J Stud Alcohol B 29 (1968) 130-151.

2. de Lint J, Schmidt W. Consumption averages and al- coholism prevalence: A brief review of epidemiological investigations. Br J Addict 66 (1971) 97-107.

3. Guralnick L. Mortality by occupation and industry among men 20 to 64 years of age: United States, 1950 Vital Stat Spec Rep 53 (1961) 91-339.

4. Hingson R, Mangione T, Barret J. Job characteristics and drinking practices in the Boston metropolitan area. J Stud Alcohol 42 (1981) 725-738.

5. Öjesjö L, Hagnell $O$, Lanke J. Class variations in the incidence of alcoholics in the Lundby Study, Sweden. Soc Psychiatry 18 (1983) 123-128.

6. Park P. Social-class factors in alcoholism. In: Kissin $\mathbf{R}$, Begleiter $\mathbf{H}$, ed. The pathogenesis of alcoholism, psychosocial factors. Plenum Press, New York and London 1983, pp 365-404.

7. Plant MA. Occupations and alcohol-related problems. Br J Alcohol Alcohol 3 (1979) 119-120.

8. Plant MA. Occupations, drinking patterns and alcohol-related problems: Conclusions from a followup study. Br J Addict 74 (1979) 267-273.

9. Rautanen-Saari L. Työelämän alkoholiongelmat ja hoitoonohjaus: Kahden hoitoonohjauskäytännön tarkastelu [Problem drinking, work and referral to treatment: A survey of two referral systems]. Alkoholipoliittisen tutkimuslaitos, Helsinki 1980. (Alkoholipoliittisen tutkimuslaitoksen tutkimusseloste no 141). (English abstract).

10. Roman PM, Trice HM. The development of deviant drinking behavior. Arch Environ Health 20 (1970) 424-435.

11. Salaspuro A. Alkoholiin liittynyt terveyspalvelukäyttö Suomessa vuonna 1972. Alkoholitutkimussäätiö, Helsinki 1978. (Alkoholitutkimussäätiön julkaisuja no 29).

12. Simpura J. Suomalaisten juomatavat vuosina 1969 ja 1976: Kulutetut alkoholimäärät ja alkoholin ongelmakäyttö [Finnish drinking habits in 1969 and 1976: Alcohol consumption and alcohol problems in demographic groups]. Alkoholipoliittisen tutkimuslaitos, Helsinki 1978. (Alkoholipoliittisen tutkimuslaitoksen tutkimusseloste no 114). (English abstract).

13. Von Wiegand RA. Alcoholism in industry (USA). $\mathrm{Br}$ J Addict 67 (1972) 181-187.

14. Whitehead PC, Simpkins J. Occupational factors in alcoholism. In: Kissin R, Begleiter $\mathbf{H}$, ed. The pathogenesis of alcoholism, psychosocial factors. Plenum Press, New York and London 1983, pp 405-553. 